\title{
Effect of temporary vascular shunting as a previous intervention on lower extremity arterial injury: Single center experiences in the Syrian Civil War
}

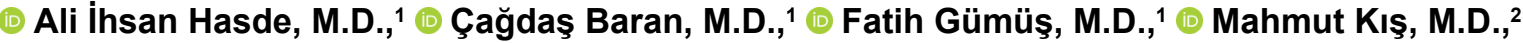

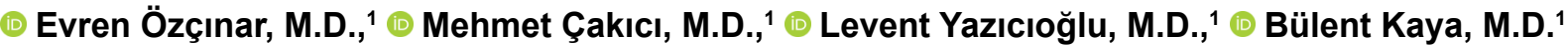

\author{
1Department of Cardiovascular Surgery, Ankara University Faculty of Medicine, Ankara-Turkey \\ ${ }^{2}$ Depatment of Cardiovascular Surgery, Hatay State Hospital, Hatay-Turkey
}

\begin{abstract}
BACKGROUND: The goal of this retrospective study was to clarify the effect of using temporary vascular shunt (TVS) as a previous intervention.

METHODS: A total of 96 cases with war-related lower extremity arterial injury and surgically treated between October 2013 and March 2016 were included in the study. The patients were divided into two groups: those in which TVS was performed as a previous intervention on admission (TVS group, $\mathrm{n}=24$ ) and those in which compression, tourniquet, and ligation/clampage were performed as a previous intervention on admission (non-TVS group, $\mathrm{n}=72$ ).

RESULTS: In comparing injury pattern, there was no difference between the two groups. In addition, mean hematocrit level, mean systolic blood pressure, the incidence of concomitant vein injury, nerve injury, soft tissue damage, and bone injury were similar in both groups. The overall amputation rate was $19 \%$. There were a total of 18 amputations, with I (4\%) in the TVS group and I7 (24\%) in the non-TVS group. The difference on amputation rate was statistically significant. The mean values of the mangled extremity severity score (MESS) were 6.45 in the TVS group and 7.44 in the non-TVS group. The overall mean MESS was 7.I. The duration of ischemia (Dol) was $4.84 \pm \mathrm{l} .84 \mathrm{~h}$ in the TVS group and $5.95 \pm \mathrm{I} .92 \mathrm{~h}$ in the non-TVS group. These differences in MESS and Dol were statistically significant.
\end{abstract}

CONCLUSION: We think that it may be beneficial for patients to consider a TVS to reduce Dol and gain time for surgical revascularization. As a result, the present study demonstrates that the use of TVS may successfully serve as a bridge between initial injury and definitive repair with a reduction in amputation rates.

Keywords: Amputation; arterial injuries; temporary vascular shunt; war.

\section{INTRODUCTION}

War leads to disastrous results for both military personnel and civilians. Vascular lesions appear in approximately $10 \%$ of war-related injuries with extremity injuries accounting for $75 \%$ of this amount. ${ }^{[1]}$ Osseous, nerve, vein, and soft tissue injuries may be concomitant with arterial injuries.

The management of war-related extremity injuries is chal- lenging; if not properly managed, these injuries may result in such significant outcomes as limb loss or death. ${ }^{[2]}$

Vascular injuries sustained during both World War I and II were routinely managed with simple ligation. ${ }^{[3]}$ The approach and timing of vascular repair in patients with complex extremity injuries can prove difficult and time consuming. In 197I, Eger et al. ${ }^{[4]}$ were among the first to describe the use of a temporary vascular shunt (TVS) for a popliteal artery injury

Cite this article as: Hasde Aİ, Baran Ç, Gümüş F, Kış M, Özçınar E, Çakıcı M, et al. Effect of temporary vascular shunting as a previous intervention on lower extremity arterial injury: Single center experiences in the Syrian Civil War. Ulus Travma Acil Cerrahi Derg 2019;25:389-395.

Address for correspondence: Ali İhsan Hasde, M.D.

Ankara Üniversitesi Tıp Fakültesi, Kalp ve Damar Cerrahisi Anabilim Dalı, Ankara, Turkey

Tel: +90 312 - 5956084 E-mail: ahasde@gmail.com

Ulus Travma Acil Cerrahi Derg 2019;25(4):389-395 DOI: 10.5505/tites.2018.29302 Submitted: 24.09.2018 Accepted: 23.1I.2018 Online: 08.07.2019

Copyright 2019 Turkish Association of Trauma and Emergency Surgery 
temporarily restoring perfusion to an injured limb while bone fracture fixation occurred. TVSs have since been used and are well described in the civilian literature as an adjunct for the treatment of peripheral vascular injuries. ${ }^{[5-8]}$

The goal of this retrospective study was to clarify the effect of TVS as a previous intervention in cases of war-related arterial injuries.

\section{MATERIALS AND METHODS}

\section{Study Design and Patients}

In this retrospective study, data were collected from the medical records of Hatay State Hospital, Hatay, Turkey. One hundred two patients with lower extremity arterial injuries suffered during the Syrian Civil War between October 2013 and March 2016 were evaluated. Six patients on whom primary amputation had already been performed without any surgical vascular intervention were excluded from the study. The decision for primary amputation in these cases had been decided by a cardiovascular surgeon, an orthopedist, and a plastic surgeon based on medical experience, viability of the injured extremity, life-threatening condition, massive tissue loss, gross contamination, and mangled extremity severity score (MESS) (Table I). All patients had had a previous intervention at the battle site, including compression $(n=34$, $35 \%)$, TVS $(n=24,25 \%)$, tourniquet $(n=20,21 \%)$, and ligation/ clampage $(n=18,19 \%)$ and were then admitted to our center (Table 2). Ninety-six patients were divided into two groups: those in which TVS was performed as a previous intervention on admission (TVS group, $\mathrm{n}=24$ ) and those in which compression, tourniquet, and ligation/clampage were performed as a previous intervention on admission (non-TVS group, $n=72$ ). The individual medical records were reviewed to analyze the following variables: age, gender, mechanism of injury, clinical findings, MESS, duration of ischemia (Dol), concomitant injuries, surgical procedures and interventions, wound infection, rate of amputation, and mortality (Table 3 ). First, the patients were evaluated in the emergency services. The evaluation of the arterial injury was mostly undertaken by physical examination. Indications for vascular surgical intervention were defined as follows: signs of leg ischemia, reduced or absent distal pulse, arterial bleeding, expanding hematoma, pulsatile hematoma, the presence of thrill or murmur, and performing definitive repair at the injury site. Primary endpoints were MESS, Dol, and rate of amputation.

\section{Surgical Management}

Operative exploration of these cases varied. In cases of injuries caused by bullets, exploration was performed according to standard arterial exposure. In patients with severe tissue loss due to explosive devices and following hemodynamic stabilization and wound decontamination, exploration was conducted to expose and repair vascular structure as soon as proven possible. Arterial injuries were repaired prior
Table I. Mangled extremity severity score

\section{Variables}

Skeletal/soft tissue injury

Low energy (stab, simple fracture, pistol

gunshot wounds)

Medium energy (open or multiple fractures,

dislocation)

High energy (high speed MVA or rifle gunshot

wound)

Very high energy (high speed trauma+gross

contamination)

Limb ischemia

Pulse reduced or absent but perfusion normal

Pulseless, paresthesias, diminished capillary refill

Coll, paralyzed, insensate, numb

Shock

Systolic blood pressure always $>90 \mathrm{mmHg}$

Hypotensive transiently

Persistent hypotension

Age (years)

$<30$

30-50

$>50$

ascore doubled for ischemia $>6 \mathrm{~h}$. MVA: Motor vehicle accident.

Table 2. Distributions of previous interventions on admission

\begin{tabular}{llr}
\hline Previous intervention & \multicolumn{2}{c}{$\mathbf{n = 9 6}$} \\
\cline { 2 - 3 } & $\mathbf{n}$ & $\%$ \\
\hline Compression & 34 & 35 \\
Temporary vascular shunt & 24 & 25 \\
Tourniquet & 20 & 21 \\
Ligation/clampage & 18 & 19 \\
\hline
\end{tabular}

to bone, nerve, and tendon repair. Thereafter, clamping to the proximal and distal sides of the site of injury was conducted. In patients in the TVS group, shunts were removed after clamping. Systemic heparinization was performed except for a great deal of soft tissue and muscle destruction. Fogarty catheters were routinely used proximally and distally to remove any thrombus. Primary repair or end to end anastomosis was preferred, but where it was not possible, the greater saphenous vein of an uninjured leg or polytetrafluoroethylene graft was used for interposition graft. Polypropylene sutures were used for anastomosis. Concomitant vein injuries were repaired whenever possible. All patients with associated orthopedic injuries underwent reduction of bone 
Table 3. Demographics, features of injuries, and findings of patients

\begin{tabular}{|c|c|c|c|c|}
\hline & $\begin{array}{l}\text { Overall } \\
(n=96)\end{array}$ & $\begin{array}{l}\text { TVS group } \\
(n=24)\end{array}$ & $\begin{array}{l}\text { Non TVS group } \\
\quad(n=72)\end{array}$ & $\underset{(p<0.05)}{p}$ \\
\hline Age, mean $\pm S D$ & $28.32 \pm 10.16$ & $28.04 \pm 10.06$ & $28.41 \pm 10.33$ & $0.87^{a}$ \\
\hline Gender (male) & $91(95)$ & $22(92)$ & $69(96)$ & $0.59^{\mathrm{b}}$ \\
\hline \multicolumn{5}{|l|}{ Injury mechanism, n (\%) } \\
\hline Gunshot & $46(48)$ & $14(58)$ & $32(44)$ & $0.25^{\mathrm{b}}$ \\
\hline Explosive & $50(52)$ & $10(42)$ & $40(56)$ & \\
\hline \multicolumn{5}{|l|}{ Clinical findings on admission } \\
\hline Hematocrit (\%), mean \pm SD & $29.12 \pm 4.24$ & $29.85 \pm 3.63$ & $28.7 \pm 4.48$ & $0.25^{\mathrm{a}}$ \\
\hline Systolic blood pressure $(\mathrm{mmHg})$, mean $\pm \mathrm{SD}$ & $92.47 \pm 9.1$ & $94.9 \pm 9.24$ & $91.6 \pm 8.81$ & $0.08^{\mathrm{a}}$ \\
\hline \multicolumn{5}{|l|}{ Injured vascular structure, n (\%) } \\
\hline Arterial & $49(5 \mathrm{I})$ & $13(54)$ & $36(50)$ & $0.8 \mathrm{I}^{\mathrm{b}}$ \\
\hline Arterial and vein & $47(49)$ & II (46) & $36(50)$ & $0.8 \mathrm{I}^{\mathrm{b}}$ \\
\hline Bone fracture, $n(\%)$ & $37(39)$ & $8(33)$ & $29(40)$ & $0.63^{b}$ \\
\hline Major soft tissue disruption, $\mathrm{n}(\%)$ & $39(4 I)$ & II (39) & $28(46)$ & $0.63^{\mathrm{b}}$ \\
\hline Major nerve injury, $\mathrm{n}(\%)$ & $26(27)$ & $8(33)$ & $18(25)$ & $0.43^{b}$ \\
\hline Mangled extremity severity score, mean \pm SD & $7.17 \pm 1.75$ & $6.45 \pm 1.67$ & $7.44 \pm 1.82$ & $0.02^{\mathrm{a}}$ \\
\hline Duration of ischemia, mean $\pm S D$ & $5.37 \pm 1.91$ & $4.84 \pm 1.84$ & $5.95 \pm 1.92$ & $0.016^{\mathrm{a}}$ \\
\hline Fasciotomy, n (\%) & $40(42)$ & $7(29)$ & $33(46)$ & $0.23^{b}$ \\
\hline Wound infection, $\mathrm{n}(\%)$ & $25(26)$ & $5(2 I)$ & $20(28)$ & $0.59^{\mathrm{b}}$ \\
\hline Amputation, n (\%) & $18(19)$ & I (4) & $17(24)$ & $0.037^{b}$ \\
\hline Mortality, n (\%) & $0(0)$ & $0(0)$ & $0(0)$ & 1.00 \\
\hline
\end{tabular}

aStudent's t-test, ' Fisher's exact test. TVS: Temporary vascular shunt; SD: Standard deviation.

fracture and immobilization by internal or external fixation. Concomitant soft tissue, tendon, and most nerve injuries were repaired at the same time. After revascularization, fasciotomy was performed therapeutically if compartment syndrome (the compression of nerves, blood vessels, and muscle inside a closed space or compartment, leading to tissue death from the lack of oxygenation as a consequence of the increased pressure within the compartment) developed on admission and prophylactically in case of preoperative pulse deficit with ischemic time $>6 \mathrm{~h}$ and/or with major soft tissue disruption. In the postoperative period, low molecular weight heparin was used for all patients. The decision for secondary amputation was decided after surgical intervention in the event of weak/faint pulse, coldness of extremity, massive soft tissue loss, existing massive infection, or other life-threatening condition.

\section{Statistical Analysis}

Statistical analysis was performed using SPSS version 16.0 for Windows (SPSS Inc., Chicago, IL, USA). Mean and standard deviation were calculated for continuous variables. Descriptive data were compared by Student's t-test for means. For comparison of qualitative data, the Pearson chi-square test with Yate's correction or Fisher's exact test was used. A p value of $<0.05$ was considered as significant.

\section{RESULTS}

One hundred two cases with war-related arterial injury were transferred to the emergency services, and overall amputation rate (primary and secondary) was 23\% (24 of 102 patients). Six cases on whom primary amputation had been performed were excluded from the study. On admission, we realized that some form of intervention (compression, TVS, tourniquet, or ligation/clampage) had been applied to all patients at a different first aid center/health institution near the battle sites. Ninety-six patients were divided into two groups: those in which TVS was performed as a previous intervention on admission (TVS group, $\mathrm{n}=24$ ) and those in which compression, tourniquet, and ligation/clampage were performed as a previous intervention on admission (non-TVS group, $n=72$ ) (Table 2). Table 3 demonstrates the patient demographics with respect to average age, gender, mechanism of injury, clinical findings, concomitant pathologies, MESS, Dol, and amputations. The study comprised 91 (95\%) male patients, with $22(92 \%)$ in the TVS group and $69(96 \%)$ in the non-TVS group. The mean age of the patients was 28.3 (13-57) years (Table 3).

In comparing injury pattern, there was no difference between the two groups. In addition, mean hematocrit level, mean 
Table 4. Distributions of arterial injuries and types of surgical procedures

\begin{tabular}{|c|c|c|c|c|}
\hline & $\begin{array}{c}\text { Overall } \\
(n=\mid I 8)\end{array}$ & $\begin{array}{l}\text { TVS group } \\
(n=26)\end{array}$ & $\begin{array}{l}\text { Non TVS group } \\
\quad(n=92)\end{array}$ & $\underset{(p<0.05)}{p}$ \\
\hline \multicolumn{5}{|l|}{ Artery injured, $n(\%)$} \\
\hline Femoral arteries & $45(38)$ & $12(46)$ & $33(36)$ & 0.36 \\
\hline Popliteal artery & $37(3 I)$ & $9(35)$ & $28(30)$ & 0.81 \\
\hline Crural arteries & $36(3 I)$ & $5(19)$ & $31(34)$ & 0.23 \\
\hline \multicolumn{5}{|l|}{ Arterial procedure, $\mathrm{n}(\%)$} \\
\hline End to end anastomosis & $40(34)$ & $9(35)$ & $31(34)$ & 1.00 \\
\hline Saphenous vein interposition & $55(47)$ & $13(50)$ & $42(46)$ & 0.82 \\
\hline Polytetraflouroethylene & $23(19)$ & $4(15)$ & $19(20)$ & 0.77 \\
\hline Vein injuries & $\mathrm{n}=61 \quad(\%)$ & $n=20(\%)$ & $n=41$ (\%) & \\
\hline Vein repair, n (\%) & $46(75)$ & $14(70)$ & $32(78)$ & 0.53 \\
\hline
\end{tabular}

systolic blood pressure, the incidence of concomitant vein injury, nerve injury, soft tissue damage, and bone injury were similar in both groups (Table 3).

The overall amputation rate was 19\%. There were a total of I8 amputations, with I (4\%) in the TVS group and 17 (24\%) in the non-TVS group. The difference on amputation rate was statistically significant.

The mean values of the MESS were 6.45 in the TVS group and 7.44 in the non-TVS group. The overall mean MESS was 7.I. The Dol was $4.84 \pm \mathrm{I} .84 \mathrm{~h}$ in the TVS group and $5.95 \pm \mathrm{I} .92 \mathrm{~h}$ in the non-TVS group. These differences in MESS and Dol were statistically significant.

There were II8 arteries and 61 veins injured in the 96 cases. Combined artery and vein injuries were determined in 47 patients. All arteries and 46 of 61 veins were repaired (I5 calf veins were ligated). The injured vascular structures and the surgical procedures performed are compiled in Table 4 (Fig. Ia-c).

Fasciotomy was performed on 40 (42\%) patients who had combined artery and vein injuries, Dol $>6 \mathrm{~h}$, and compart- ment syndrome. Among these patients, secondary amputation was performed on $13(33 \%)$ patients (I patient in the TVS group and 12 patients in the non-TVS group).

The overall wound infection rate was $26 \%$ (25 patients, with 5 patients in the TVS group and 20 patients in the non-TVS group). Infectious agents were Staphylococcus aureus in 12 cases, Acinetobacter baumannii in 5, Pseudomonas aeruginosa in 3, Escherichia coli in 2, Citrobacter koseri in I, Cedecea lapagei in I, and Staphylococcus gallinarum in I.

The etiology of the amputation was graft thrombosis in II (61\%) cases, wound infection leading to sepsis in $4(22 \%)$ cases, and extensive soft tissue loss in 3 (17\%) cases. There was no mortality in the hospital.

\section{DISCUSSION}

War-related arterial injuries are a challenge to manage and may result in different ways, from simple injuries caused by low energy basic devices to complex injuries caused by high energy explosive and destructive devices. ${ }^{[1-3,9,10]}$ We are now regularly encountering these kinds of injuries due to the Syrian Civil War in parallel to the literature. The hospital where the injured people are treated is located in Hatay,
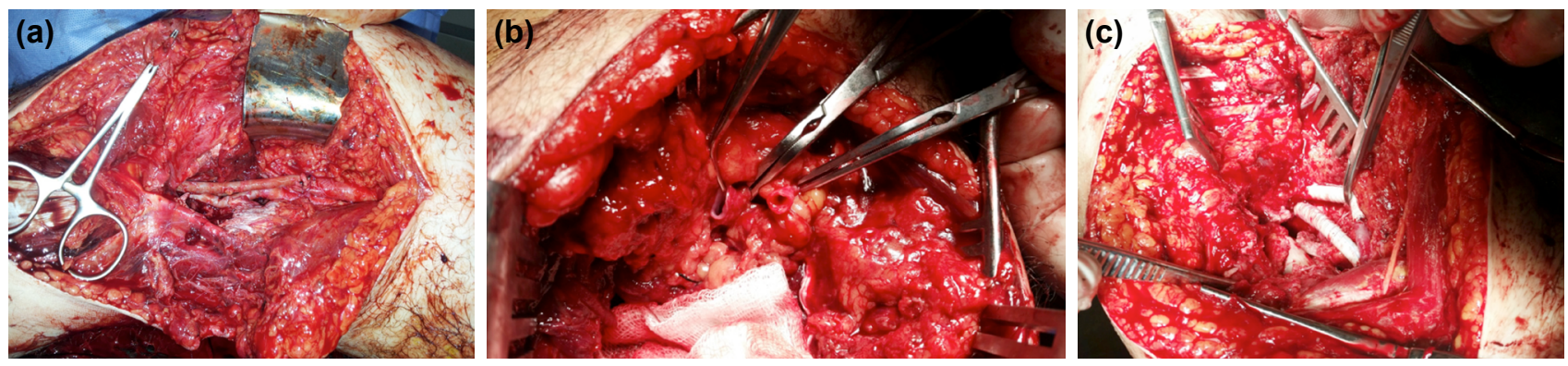

Figure 1. (a) Repair of popliteal artery and vein with saphenous vein interposition. (b) Proximal side of femoral artery and vein, after resection of injured side. (c) Repair of femoral artery and vein with polytetrafluoroethylene graft interposition. 
near the border with Syria in southernmost Turkey. There are some difficulties, and especially constraints, in making diagnoses because the hospital is only a level 2 civil healthcare institution, so it has no advanced technical facilities. In the main, patients were diagnosed by physical examination, whereas computed tomography angiography, the gold standard method for diagnosis, and Doppler ultrasonography were rarely used (Fig. 2). ${ }^{[1]}$

In previous years, most war-related injuries encountered were shooting injuries, but following the Iraq and Afghanistan wars, it was realized that the majority of such injuries were now caused by high powered and destructive weapons developed in parallel with advancements in technology. ${ }^{\left[{ }^{[I]}\right.}$ We have subsequently seen even bigger and more complex injuries in the Syrian Civil War. The first patient interventions had been done by local healthcare teams in places near to the different war areas. After medical or surgical intervention, the patients were transferred away from the border and brought to our healthcare institution by a Turkish emergency team. An urgent first intervention has quite an important effect in precluding amputation. Most of the wounds seen in the early stages of the war were initially treated by compression, tourniquet, and ligation/clamping. However, in the main, a TVS had been applied to patients who were brought in during the later periods of the war by the first intervention team. The aim of our study was to analyze the effect of TVS after extremity vascular injury. The protection of vital organs and the use of tourniquets in the field have led to an increase in the number of patients presenting to military treatment facilities with extremity and peripheral vascular injuries. In addition, strategically placed forward surgical capability allows for earlier extremity vascular injury assessment. The use of TVSs has emerged as a viable treatment option for military

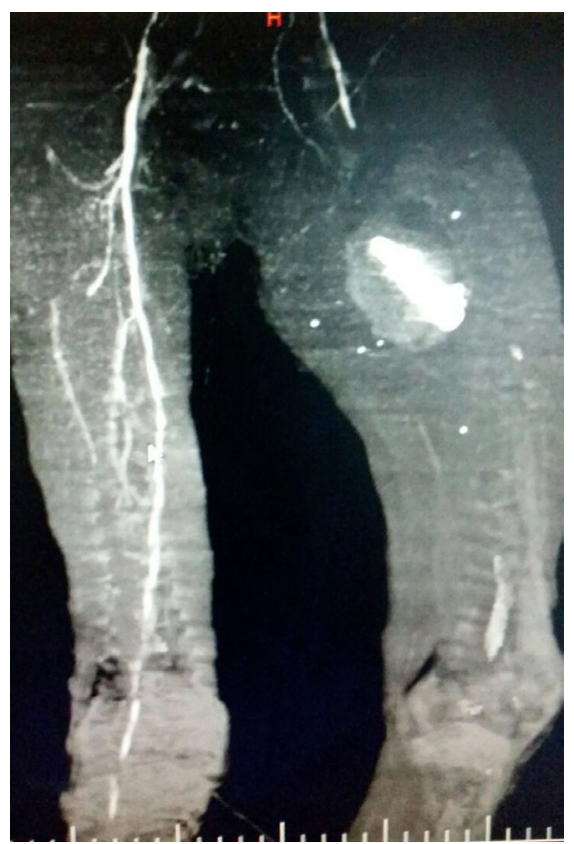

Figure 2. Image of computed tomography angiography. surgeons in the forward operating arena and has proven successful for hemorrhage control, shorter ischemia time, and temporary limb perfusion. ${ }^{[2]}$ Temporary vascular shunting is a method of timely restoration of flow and is well described in settings of damage control in both the military and civilian sectors. Seemingly important during times of hemodynamic instability, re-warming, and acid-base correction, shunts have also been used during extremity stabilization after initial injury exploration. ${ }^{[4,13,14]}$ Rush et al. ${ }^{[15]}$ expressed that ischemia duration is the most important factor related to amputation independent from MESS.

Consistent with the literature, femoral artery injuries were the most commonly injured arterial structures in our study and comprise almost $38 \%$ of all arterial traumas compared in the recent series. ${ }^{[16]}$ Regarding the management of vascular injuries, reversed saphenous vein was the most commonly preferred and used graft in repair for our series in accordance with the literature. ${ }^{[17]}$ In many studies, fasciotomy and vein repair are recommended especially in patients who have combined arterial and venous insufficiency, have Dol $>6 \mathrm{~h}$, or where bone and soft tissue trauma associated with vascular injury and compartmental pressures have risen seriously. ${ }^{[18,19]}$ Clouse et al. ${ }^{[18]}$ emphasized that a venous injury associated with an arterial injury is seen in all of the early amputated patients in their study. Gifford et al. ${ }^{[20]}$ reported that the rate of fasciotomy they performed in their patients is $63 \%$, but the rate of secondary amputation is lower at $14 \%$. In our study, combined arterial and vein injuries, rate of vein repair, and performing fasciotomy were similar in both groups.

Many scoring systems that aid in the amputation decision in cases of serious lower extremity injuries have so far been defined. ${ }^{[2]}$ The MESS described by Johansen was used to determine the viability of an extremity after trauma. According to the author, when the score is $<7$, limb-salvage can be performed; if it is $>7$, amputation is recommended. The MESS was determined upon admission. ${ }^{[22]}$ MESS is one of these scoring systems, providing an idea of the viability of an extremity after trauma and whether to undergo amputation. Brown et al. ${ }^{[23]}$ reported that the extremity is preserved in $35.7 \%$ of the patients whose MESS is $\geq 7$, although this score in fact indicates a high probability of amputation. Şişli et al. ${ }^{[24]}$ found in their study that the extremity is kept in $60 \%$ of patients who have MESS $>7$, and that the MESS scoring system is not in itself a sufficient criterion to determine amputation. In our study, MESS was used as a scoring system, and revascularization was performed despite the fact that 51 (53\%) of 96 patients had MESS $\geq 7$. Secondary amputation was applied to $18(35 \%)$ of these patients. In our study, MESS was lower statistically different in favor of the TVS group $(6.45 \pm 1.67$ vs. $7.44 \pm 1.82)(p<0.05)$. This may be explained by shorter Dol in patients in the TVS group.

Performing a TVS provides urgent and effective control of bleeding and sufficient distal perfusion after major vascular 
injury. Barros et al. ${ }^{[25]}$ showed that amputation rate decreases from $32.4 \%$ to $39.5 \%$ and from $8.8 \%$ to $14.3 \%$ in patients where a TVS was performed. In our study, Dol and amputation rates were significantly lower in favor of the TVS group $(p<0.05)$. In the current study, we emphasize being able to perform a TVS as the first intervention is really important in enabling patients with lower extremity arterial injuries to keep those extremities because it provides time to surgeons to cope with the negative effects of ischemia and undertake bleeding control and revascularization.

In conclusion, the aim of the present study was to analyze the effect of using TVS as a previous intervention. We think that it may be beneficial for patients to consider a TVS to reduce Dol and gain time for surgical revascularization. As a result, the present study demonstrates that the use of TVS may successfully serve as a bridge between initial injury and definitive repair with a reduction in amputation rates.

\section{Conflict of interest: None declared.}

\section{REFERENCES}

1. Fox CJ, Patel B, Clouse WD. Update on wartime vascular injury. Perspect Vasc Surg Endovasc Ther 2011;23:13-25. [CrossRef]

2. Weaver FA, Papanicolaou G, Yellin AE. Difficult peripheral vascular injuries. Surg Clin North Am 1996;76:843-59. [CrossRef]

3. DeBakey ME, Simeone FA. Battle injuries of the arteries in World War II; an analysis of 2,471 cases. Ann Surg 1946;123:534-79. [CrossRef]

4. Eger M, Golcman L, Goldstein A, Hirsch M. The use of a temporary shunt in the management of arterial vascular injuries. Surg Gynecol Obstet 1971;132:67-70.

5. Barros D'Sa AA, Moorehead RJ. Combined arterial and venous intraluminal shunting in major trauma of the lower limb. Eur J Vasc Surg 1989;3:577-81. [CrossRef]

6. Nalbandian MM, Maldonado TS, Cushman J, Jacobowitz GJ, Lamparello PJ, Riles TS. Successful limb reperfusion using prolonged intravascular shunting in a case of an unstable trauma patient--a case report. Vasc Endovascular Surg 2004;38:375-9. [CrossRef]

7. Davins M, Llagostera S, Lamas C, López S. Role of temporary arterial shunt in the reimplantation of a traumatic above-elbow amputation. Vascular 2007;15:176-8. [CrossRef]

8. Nunley JA, Koman LA, Urbaniak JR. Arterial shunting as an adjunct to major limb revascularization. Ann Surg 1981;193:271-3. [CrossRef]

9. Davidovic LB, Cinara IS, Ille T, Kostic DM, Dragas MV, Markovic DM. Civil and war peripheral arterial trauma: review of risk factors associated with limb loss. Vascular 2005;13:141-7. [CrossRef]

10. Haddock NT, Weichman KE, Reformat DD, Kligman BE, Levine JP, Saadeh PB. Lower extremity arterial injury patterns and reconstructive outcomes in patients with severe lower extremity trauma: a 26 -year re- view. J Am Coll Surg 2010;210:66-2. [CrossRef]

11. Eskridge SL, Macera CA, Galarneau MR, Holbrook TL, Woodruff SI, MacGregor AJ, et al. Injuries from combat explosions in Iraq: injury type, location, and severity. Injury 2012;43:1678-82. [CrossRef]

12. Taller J, Kamdar JP, Greene JA, Morgan RA, Blankenship CL, Dabrowski $\mathrm{P}$, et al. Temporary vascular shunts as initial treatment of proximal extremity vascular injuries during combat operations: the new standard of care at Echelon II facilities? J Trauma 2008;65:595-603. [CrossRef]

13. Chambers LW, Green DJ, Sample K, Gillingham BL, Rhee P, Brown C, et al. Tactical surgical intervention with temporary shunting of peripheral vascular trauma sustained during Operation Iraqi Freedom: one unit's experience. J Trauma 2006;61:824-30. [CrossRef]

14. Rasmussen TE, Clouse WD, Jenkins DH, Peck MA, Eliason JL, Smith DL. The use of temporary vascular shunts as a damage control adjunct in the management of wartime vascular injury. J Trauma 2006;61:8-12.

15. Rush RM Jr, Kjorstad R, Starnes BW, Arrington E, Devine JD, Andersen CA. Application of the Mangled Extremity Severity Score in a combat setting. Mil Med 2007;172:777-81. [CrossRef]

16. Prichayudh S, Verananvattna A, Sriussadaporn S, Sriussadaporn S, Kritayakirana $\mathrm{K}, \mathrm{Pak}$-art $\mathrm{R}$, et al. Management of upper extremity vascular injury: outcome related to the Mangled Extremity Severity Score. World J Surg 2009;33:857-63. [CrossRef]

17. Carrillo EH, Spain DA, Miller FB, Richardson JD. Femoral vessel injuries. Surg Clin North Am 2002;82:49-65. [CrossRef]

18. Clouse WD, Rasmussen TE, Peck MA, Eliason JL, Cox MW, Bowser AN, et al. In-theater management of vascular injury: 2 years of the Balad Vascular Registry. J Am Coll Surg 2007;204:625-32. [CrossRef]

19. Dua A, Patel B, Desai SS, Holcomb JB, Wade CE, Coogan S, et al. Comparison of military and civilian popliteal artery trauma outcomes. J Vasc Surg 2014;59:1628-32. [CrossRef]

20. Gifford SM, Aidinian G, Clouse WD, Fox CJ, Porras CA, Jones WT, et al. Effect of temporary shunting on extremity vascular injury: an outcome analysis from the Global War on Terror vascular injury initiative. J Vasc Surg 2009;50:549-55. [CrossRef]

21. Krettek C, Seekamp A, Köntopp H, Tscherne H. Hannover Fracture Scale '98--re-evaluation and new perspectives of an established extremity salvage score. Injury 2001;32:317-28. [CrossRef]

22. Johansen K, Daines M, Howey T, Helfet D, Hansen ST Jr. Objective criteria accurately predict amputation following lower extremity trauma. J Trauma 1990;30:568-72. [CrossRef]

23. Brown KV, Ramasamy A, McLeod J, Stapley S, Clasper JC. Predicting the need for early amputation in ballistic mangled extremity injuries. J Trauma 2009;66:S93-7. [CrossRef]

24. Şişli E, Kavala AA, Mavi M, Sarıosmanoğlu ON, Oto Ö. Single centre experience of combat-related vascular injury in victims of Syrian conflict: Retrospective evaluation of risk factors associated with amputation. Injury 2016;47:1945-50. [CrossRef]

25. Barros D'Sa AA, Harkin DW, Blair PH, Hood JM, McIlrath E. The Belfast approach to managing complex lower limb vascular injuries. Eur J Vasc Endovasc Surg 2006;32:246-56. [CrossRef] 
ORIJINAL ÇALIŞMA - ÖZET

\section{Alt ekstremite arteriyel yaralanmalarında ilk müdahalede geçici vasküler şant uygulamasının etkileri: Suriye iç savaşında tek merkez deneyimleri \\ Dr. Ali İhsan Hasde, ${ }^{1}$ Dr. Çağdaş Baran, ${ }^{1}$ Dr. Fatih Gümüş, ${ }^{1}$ Dr. Mahmut Kış, ${ }^{2}$ \\ Dr. Evren Özçınar, ${ }^{1}$ Dr. Mehmet Çakıcı,, ${ }^{1}$ Dr. Levent Yazıcıoğlu, ${ }^{1}$ Dr. Bülent Kaya ${ }^{1}$}

${ }^{1}$ Ankara Üniversitesi Tıp Fakültesi, Kalp ve Damar Cerrahisi Anabilim Dalı, Ankara

${ }^{2}$ Hatay Devlet Hastanesi, Kalp ve Damar Cerrahisi Kliniği, Hatay

AMAÇ: Bu geriye dönük çalışmanın amacı, ateşli silah yaralanmalarında ilk müdahelede geçici vasküler şant (GVŞ) uygulamasının etkilerini irdelemektir. GEREÇ VE YÖNTEM: Ekim 2013 ve Mart 2016 tarihleri arasında ateşli silah yaralanması nedeniyle ameliyat edilen 96 hasta çalışmaya alındı. Hastalar; ilk girişim olarak GVŞ uygulanan hastalar (GVŞ grubu, $n=24$ ) ve ilk girişim olarak kompresyon, turnike ve ligasyon/klempaj uygulanan hastalar (GVŞ yapılmayan grup, $\mathrm{n}=72$ ) olmak üzere iki gruba ayrıldı.

BULGULAR: Yaralanma mekanizması karşılaştırıldığında, her iki grup arasında fark yoktu. Aynı şekilde ortalama hematokrit seviyesi, ortalama sistolik kan basıncı, eşlik eden ven ile sinir ve yumuşak doku ve kemik yaralanmaları her iki grupta benzerdi. Tüm ampütasyon oranı \%।9 idi. Biri GVŞ grubunda, I7'si diğer GVŞ yapılmayan hasta grubunda olmak üzere toplam ampütasyon sayısı I 8 idi. Ortalama travmaya uğramış ekstremite skoru (MESS) GVŞ grubunda 6.45 iken GVŞ yapılmayan grupta 7.44 idi. İskemi süresi GVŞ grupta $4.84 \pm 1.84$ saat iken GVŞ yapılmayan grupta $5.95 \pm 1.92$ saat idi. MESS ve iskemi süresindeki farklılık istatistiksel olarak anlamlı değerlendirildi.

TARTIŞMA: Geçici vasküler şant kullanımının iskemi süresini kısaltmak ve cerrahi revaskülarizayon için zaman kazandırması bakımından hastalar için faydalı olabileceğini düşünmekteyiz. Sonuç olarak, bu çalışma GVŞ kullanımının yaralanma başlangııından nihai cerrahi onarımına kadar başarılı bir köprü görevi gördüğünü ve ampütasyon oranını azalttığını göstermektedir.

Anahtar sözcükler: Ampütasyon; arteriyel yaralanma; geçici vasküler şant; savaş.

Ulus Travma Acil Cerrahi Derg 2019;25(4):389-395 doi: 10.5505/tjtes.2018.29302 